\title{
PRINSIP KEADILAN SOSIAL DAN ALTRUISME DALAM PENERAPAN SISTEM PERBANKAN SYARIAH
}

\author{
Siti Amaroh 1
}

\begin{abstract}
Artikel ini bertujuan untuk mengkaji tentang keadilan sosial dan altruisme dalam implementasi sistem perbankan syariah. Bank syariah menempatkan perannya dalam memobilisasi dana dan menyalurkannya kepada masyarakat dalam beragam bentuk produk berdasarkan prinsip-prinsip syariah. Pencapaian ekonomi dan sosial merupakan tujuan pokok didirikannya bank syariah. Keadilan sosial tercapai bilamana pendapatan masyarakat dapat memenubi kebutubannya dan setiap anggota masyarakat mendapatkan kesempatan yang sama dalam meningkatkan taraf bidupnya. Sedangkan altruisme merupakan bentuk kebaikan hati dalam memberikan bantuan pada pihak lain tanpa meminta imbalan. Implementasi keadilan sosial dan altruisme dalam perbankan syariah diwujudkan dalam fungsi zakat dan qardhul hasan.
\end{abstract}

Keyword: Keadilan Sosial, altruisme, zakat, Qardhul Hasan

\section{Pendahuluan}

Perbankan syariah sebagai institusi keuangan menyediakan produk dan layanan keuangan yang didesain berdasarkan prinsip syariah Islam dan telah berkembang pesat dalam industri keuangan global ${ }^{2}$. Perkembangannya di lebih dari 50 negara termasuk Amerika Serikat dan Eropa ${ }^{3}$. Awal perkembanganya dimulai sejak akhir 1940-an dan dua dekade sesudahnya di negara-negara Timur Tengah yang didirikan sebagai bagian dari aspirasi untuk memiliki bank sendiri, meskipun sebenarnya ide bank berbasis syariah atau bank Islam telah ada di awal abad ke-7. Awal 1980-an, transformasi sektor

${ }^{1}$ Dosen Jurusan Syariah dan Ekonomi Islam Sekolah Tinggi Agama Islam Negeri Kudus amar_stainkudus@yahoo.co.id

2 Bruce Hearn., et al., 2012, Islamic Finance and Market Segmentation: Implications of the Cost of Capital, International Business Review, 21, hlm. 102

3 Anjum Siddiqui, 2008, Financial Contracts, Risk and Performance of Islamic Banking, Managerial Finance, Vol. 34, No. 10, hlm. 680

Volume V/Edisi 2/Oktober 2014 


\section{Prinsip Keadilan Sosial dan Altruisme dalam Penerapan Sistem}

ekonomi dan keuangan pada jalur Islam yang dilakukan oleh tiga negara yaitu Iran, Pakistan, dan Sudan direspon oleh pemain pasar keuangan barat seperti Citibank, ABN, AMRO, HSBC dan lainnya dengan membuka sistem keuangan berbasis Islam untuk menarik dana masyarakat dari negara-negara penghasil minyak dari Timur Tengah dan umat muslim lainnya pada pasar lokal.

Bank syariah berbeda dengan bank konvensional karena melarang riba (interest) sehingga tidak diperbolehkan menawarkan produk dengan fixed-rate return pada penghimpunan dan penyaluran dana. Hubungan antara manajemen (agent) dan pemilik (principals) merupakan hubungan antara manajemen (agent) dan stakebolders (principals). Oleh karena itu maka struktur tata kelolanya bank syariah melibatkan banyak pihak sehingga memiliki batasan hak, kewenangan dan kewajiban dari setiap unsur tersebut. Berdasarkan paradigma ini maka kinerja sosial bank syariah tidak terfokus pada pihak-pihak yang memiliki kepentingan langsung terhadap bank syariah saja tetapi juga menyangkut kepentingan masyarakat yang luas dalam hal ini adalah umat.

Stakeholders terpenting bank syariah adalah Islam itu sendiri karena bank syariah memakai label Islam sehingga memiliki tanggung jawab yang besar untuk menjaga citra Islam ${ }^{4}$. Permasalahan yang berkaitan dengan penyimpangan dan kegagalan usaha bank syariah maka akan berdampak pada citra Islam. Undang-Undang No. 21 tahun 2008 pasal 4 menyatakan bahwa selain berkewajiban menjalankan fungsi menghimpun dan menyalurkan dana masyakarat maka Bank Umum Syariah (BUS) dan Unit Usaha Syariah (UUS) dapat menjalankan fungsi sosial dalam bentuk lembaga baitul maal yaitu menerima zakat, infaq, sedekah, hibah, atau dana sosial lainnya dan menyalurkannya kepada organisasi pengelola zakat. Selain itu BUS dan UUS juga dapat menghimpun dana sosial yang berasal dari wakaf uang dan menyalurkannya kepada pengelola wakaf (naz̧bir) sesuai dengan kehendak pemberi wakaf (wakif).

${ }^{4}$ Umer M. Chapra dan H. Ahmed, 2002, Corporate Governance in Islamic Financial Institution, Jedah:IRTI-IDB 


\section{Permasalahan}

Melihat latar belakang masalah tersebut maka dalam tulisan ini mengambil tema yaitu bagaimana prinsip keadilan sosial dan altruisme dalam penerapan perbankan syariah serta bagaimana penerapan Zakat dan qardul basan di Bank Syariah.

\section{Pembahasan}

Islam tidak mengakui pemisahan antara tujuan spiritual dan material dalam kegiatan bisnis sehingga harus tetap mempertimbangkan aspek moralitas yang disyaratkan syariat Islamh ${ }^{5}$. Menurut Dusuki, tujuan bank syariah dalam mewujudkan tujuan sosial dan ekonomi antara lain dicapai dengan: (1) memaksimalkan laba; (2) memberikan kontribusi bagi kesejahteraan sosial (social welfare); (3) menghapus kemiskinan; (4) meningkatkan perkembangan proyek-proyek yang berdayaguna dan berhasil guna dalam jangka panjang; (5) meminimalkan biaya operasional; (6) meningkatkan produk dan layanan yang berkualitas; (6) menawarkan produkproduk keuangan yang mutakhir dan kompetitif; serta (7) mendorong pelaksanaan nilai-nilai dan jalan hidup Islam dalam lingkungan internal dan masyarakat luas ${ }^{6}$.

Bank syariah didasarkan pada filosofi bisnis Islam dalam pengelolaan, produk, dan proses transaksi. Selain itu, sistem bank syariah juga mengikuti kerangka moral dan etika Islam serta memiliki komitmen sosial yang kuat. Komitmen sosial bank syariah itu sendiri dilandasi oleh prinsip persaudaraan (brotherhood) dan keadilan yang menjunjung tinggi nilai-nilai kemanusiaan sebagai tujuan utama Islam. Nilai-nilai kemanusiaan meliputi perhatian terhadap aspek psikis dan spiritual dalam diri manusia dengan tujuan pencapaian kebahagiaan di dunia dan akhirat. Oleh karena itu maka pemaksimalan output materialistik tidak akan mampu memaksimalkan

5 Rifaat Ahmed Abdel Karim, International Accounting Harmonization, Banking Regulation, and Islamic Banks, The International Journal of Accounting, 36, Hal 172

${ }^{6}$ Asyraf Wajdi Dusuki, 2008, Understanding the Objectives of Islamic Banking: a Survey of Stakeholders' Perspectives, International Journal of Islamic and Middle Eastern Finance and Management, Vol. 1, No 2, hlm. 138 
Prinsip Keadilan Sosial dan Altruisme dalam Penerapan Sistem

pencapaian tujuan tersebut jika tidak diimbangi dengan kesehatan spiritual dalam interaksi kepada sesama manusia maupun kepada Sang Pencipta.

Sebagaimana organisasi bisnis berbasis syariat Islam lainnya maka bank syariah memiliki mandat untuk menjalankan kegiatannya berdasarkan aturan dan prinsip syariah Islam. Nilai-nilai keadilan sosial (social justice), keterbukaan (fairness), dan kebaikan hati (altruism) merupakan bagian yang tidak dapat dipisahkan dari operasional bank syariah. Berdasarkan prinsip, tujuan, dan nilai-nilai yang dikembangkan dalam sistem keuangan syariah tersebut maka artikel ini akan mengkaji tentang penerapan prinsip keadilan sosial dan altruisme dalam pengembangan sistem perbankan syariah.

\section{Karakteristik Bank Syariah}

Bank syariah menjalankan kegiatannya berdasarkan transaksi yang halal, melarang transaksi berbasis riba dan kegiatan spekulatif serta mewajibkan pembayaran zakat. Riba melanggar prinsip keadilan sosial dan tidak memberi penghargaan pada pihak-pihak yang berpartisipasi pada risiko kegiatan yang didanai. Bank syariah menempatkan dirinya sebagai mitra usaha yang membagi risiko (kerugian) dan keuntungan (laba) sehingga membangun prinsip investasi dan usaha yang sehat. Hubungan kemitraan yang sehat dan harmonis akan membangun sistem perekonomian yang kuat. Pertumbuhan ekonomi pada sektor riil dengan prinsip kemitraan dan bagi hasil mencegah terjadinya bubble economy yang menghasilkan pertumbuhan semu dan rentan terhadap krisis ekonomi dan keuangan.

Bank syariah dalam menjalankan fungsinya baik penghimpunan maupun penyaluran dana didasarkan pada prinsip syariat Islam dengan berbagai jenis produk dengan akadnya. Adapun intrumen penghimpunan dana bank syariah meliputi:

1. Instrumen dengan akad titipan (wadiah). Akad ini merupakan hubungan kontraktual antara pemilik dana dan kustodian (bank). Bank sebagai pihak yang mendapatkan titipan harus menjaga dan mengembalikan kapan saja si 
peniti menghendaki. Implementasinya dalam bank syariah berbentuk current account (giro) dan saving account (tabungan berjangka) ${ }^{7}$

2. Instrumen dengan akad bagi hasil (mudharabah). Sumber dana bank syariah berasal dari deposan melalui kontrak mudharabah. Kontrak ini melibatkan salah satu pihak sebagai membantu modal untuk usaha sementara pihak lain memberikan kontribusi ketrampilan berwirausaha. Kedua belah pihak membagi keuntungan yang dihasilkan sesuai dengan kontrak yang disepakati. Dalam kasus kerugian maka pemilik modal berperan dalam menanggung risiko kerugian. Bagi deposan yang menempatkan dananya pada bank syariah maka keuntungan dibagi antara bank dengan deposan sesuai dengan rasio yang telah ditentukan dan dalam hal kerugian maka deposan ikut serta dalam menanggung risiko.

Sedangkan instrumen penyaluran dana antara lain:

1. Berdasarkan Prinsip Bagi Hasil

- Investasi tanpa partisipasi dalam manajemen (mudharabah). Instrumen ini merupakan kontrak antara 2 pihak yang mana bank sebagai pemilik modal (shabibul maal) menyediakan dana 100\% bagi pihak lain sebagai pengelola atau entrepreneur (mudharib). Bank dan entrepreneur membagi keuntungan tetapi entrepreneur tidak menanggung kerugian sepanjang kerugian tidak disebabkan oleh kelalaian entrepreneur. Namun demikian seandainya kerugian disebabkan oleh kelalaian dan kecurangan entrepreneur maka entrepreneur bertanggung jawab terhadap kerugian tersebut

- Partnership (musyarakah). Musyarakah merupakan kontrak kerjasana antara dua pihak atau lebih dimana masing-masing pihak menyediakan modal dan juga berperan dalam pengelolaan bisnis. Keuntungan dibagi berdasarkan perjanjian yang disepakati sedangkan kerugian berdasarkan proporsi modal (QS. Shad 38: 24)

2. Berdasarkan Prinsip Jual Beli hal. 87

7 Muhammas Syafi'i Antonio, 2001, Bank Syariah dari Teori ke Praktik, Gema Insani, Jakarta, 
Prinsip Keadilan Sosial dan Altruisme dalam Penerapan Sistem

- Kontrak Jual-Beli (Murabahah). Murabahah merupakan kontrak antara 2 pihak dimana bank menjual barang dengan harga tertentu termasuk tingkat keuntungan yang dikehendaki dan klien membeli barang tersebut dengan perjanjian akan membayar sesuai dengan waktu dan harga yang telah ditentukan. Harga jual tidak boleh berubah selama masa perjanjian (Q.S. An Nisaa' 4: 29)

- Pembelian dengan pembayaran dimuka (salam). Salam merupakan produk bank syariah yang berdasarkan kontrak jual beli dimana penjual yang menawarkan barang dengan spesifikasi tertentu dimana pembeli melakukan pembayaran diawal, sedangkan penyerahannya dilakukan sesuai dengan waktu yang disepakati (QS. Al Baqarah 2: 282)

- Membeli dengan memesan (istishna). Istishna adalah jual beli barang dimana produsen (shaani) ditugaskan untuk membuat suatu barang pesanan dari pemesan (mustashni) menurut spesifikasi yang telah disepakati dan pembeli dapat melakukan pembayaran baik diawal, ditengah atau diakhir pesanan dan baik dengan pembayaran tunai atau tangguh ${ }^{8}$.

3. Berdasarkan Prinsip Sewa

- Sewa (Ijarah). Ijarah merupakan pemindahan hak guna atas barang atau jasa melalui pembayaran sewa tanpa diikuti dengan pemindahan kepemilikan atas barang tersebut. Dalam hal ini atas barang yang disewakan maka bank (muajjir) mendapatkan imbalan dari klien sebagai penyewa (mustajir)

- Sewa dengan opsi kepemilikan (Ijarah Muntabia Bittamlik). Ijarah Muntahia Bittamlik merupakan perjanjian antara bank sebagai pihak yang menyewakan (muajjir) dengan klien sebagai penyewa (mustajir) yang menyepakati untuk membayar sewa terhadap barang yang disewa dan bila masa sewa berakhir maka muajjir memberikan hak opsi terhadap mustajir untuk memiliki obyek yang disewakan

4. Jasa

${ }^{8}$ Ibid, hlm. 113 
- Dana kebajikan (Qardul Hasan). Dana ini merupakan pemberian pinjaman kepada pihak lain tanpa mengharapkan imbalan dari pinjaman tersebut. Implementasi produk ini dalam sistem perbankan syariah dapat dilakukan untuk memberikan kontribusi bagi pihak-pihak tertentu dalam memberdayakan kesejahteraan sosial masyarakat. Pengembalian pinjaman ditentukan dalam jangka waktu tertentu sesuai dengan kesepakatan bersama sebesar pinjaman tanpa ada tambahan keuntungan dan pembayaran dapat dilakukan secara angsuran atau sekaligus (QS. Al Hadiid 57: 11)

- Akad pemberian wewenang (wakalah). Wakalah merupakan penyerahan, pendelegasian atau pemberian wewenang atau kuasa dari pemberi mandat kepada pihak lain/wakil untuk melaksanakan urusan dengan batas kewenangan dan waktu tertentu. Segala hak dan kewajiban yang diemban oleh wakil harus mengatasnamakan yang memberi kuasa

- Pemberian jaminan (kafalab). Kafalah adalah jaminan yang diberikan oleh penanggung (kafil) kepada pihak ketiga untuk memenuhi kewajiban pihak kedua atau yang ditanggung

- Pengalihan hutang (hawalah). Hawalah merupakan pemindahan hutang dari orang yang berhutang (mubil) sehingga menjadi tanggungan orang yang memiliki kewajiban membayar hutang tersebut (mubal'alaib)

- Gadai (Rahn). Rahn adalah menahan salah satu harta milik si peminjam sebagai jaminan atas pinjaman yang diterima. Barang yang ditahan tersebut memiliki nilai ekonomis sehingga pihak yang menahan memperoleh jaminan untuk dapat mengambil seluruh atau sebagian piutangnya

Sedangkan dalam prinsip jual beli maupun sewa maka sejumlah syarat harus dipenuhi antara lain?

${ }_{9}$ Muhammad Umer Chapra, 2009, The Global Financial Crisis: Can Islamic Finance Help?, Insights, Vol. 1, No. 4, Hlm. 33 
Prinsip Keadilan Sosial dan Altruisme dalam Penerapan Sistem

1. Aset yang diperdagangkan atau disewakan harus riil (berwujud). Syarat ini bertujuan untuk menghindari adanya transaksi derivatif dan spekulatif dalam sistem keuangan Islam

2. Penjual atau penyewa harus memiliki sendiri barang yang dijual atau disewakan. Syarat ini membantu penjual atau penyewa untuk membagi risiko dan keuntungan secara proporsional.

3. Transaksi harus merupakan transaksi perdagangan asli (genuine) yang melibatkan niat adanya penyerahan dan penerimaan barang

4. Hutang tidak dapat diperdagangkan dan risiko harus ditanggung oleh peminjam itu sendiri

\section{Prinsip Keadilan dan Tanggung Jawab Sosial}

Imam Al-Ghazali berpandangan bahwa pembangunan ekonomi yang meletakkan nilai-nilai etika dan moralitas dapat mencapai keberhasilan yang berbentuk keadilan sosial dalam masyarakat ${ }^{10}$. Integrasi ekonomi dan etika (ethico-economic) membangun sistem ekonomi yang didasarkan pada pemerataan pembangunan untuk tujuan pencegahan kesenjangan antara si kaya dan si miskin serta pembentukan peradaban manusia yang humanis.

Pandangan dunia tentang ethico-economic meliputi beberapa hal pokok ${ }^{11}$, yaitu: (1) harta dan kekayaan hanyalah sarana untuk mencapai kesejahteraan sehingga setiap proses ekonomi baik penerimaan maupun pengeluaran tidak diperbolehkan melanggar etika; (2) Tuhan sebagai pencipta adalah pemilik mutlak dari segala sesuatu, sedangkan manusia diberikan kepercayaan untuk menggunakannya berdasarkan prinsip-prinsip yang ditentukan oleh pemilik absolut; (3) untuk mendapatkan hak kepemilikan dan kepercayaan sangat tergantung pada usaha-usaha dalam mencapainya dan didasarkan pada nilainilai relevan yang harus dipatuhi; dan (4) terhadap hak yang diberikan maka harus memenuhi dua tujuan utama yaitu kesejahteraan individu (private welfare) dan kesejahteraan sosial (social welfare).

10 Ozay Mehmet, 1997, Al-Ghazzali on Social Justice: Guidelines for a New World Order from an Early Medieval Scholar, International Journal of Social Economics, hlm,. 1203-1218

11 AbulHasan M. Sadeq, 1996, ethico-economic Institution of Zakah: An Instrument of Self-Reliance and Sustainable Grassroot Developmnet, Humanomics, Vol. 12, No. 2, hlm 49 
Al Qur'an memberikan petunjuk mengenai nilai-nilai moral dan spiritualitas yang bertujuan agar setiap kecakapan diimplementasikan secara terkoordinasi dan bermanfaat ${ }^{12}$. Manusia memiliki tanggung jawab dalam setiap tindakannya dan memanfaatkan setiap kecakapan yang diberikan oleh pemilik absolute dengan tujuan memberikan kesejahteraan bagi dirinya dan juga bagi kesejahteraan sesama. Dalam Islam maka kesejahteraan tercapai manakala nilai-nilai sosial terpupuk secara menyeluruh dalam kehidupan berbangsa dan bernegara.

Salah satu implementasi pencapaian tujuan sosial adalah berkembangnya praktik-praktik kepedulian sosial dalam bentuk Corporate Social Responsibility (CSR). Tanggung jawab sosial dalam CSR dilatarbelakangi oleh beberapa faktor penting, yaitu: (1) pertimbangan etis yang berkaitan dengan hubungan organisasi bisnis dengan stakeholder dan masyarakat; (2) hubungan organisasi bisnis dengan lingkungan; dan (3) hubungan organisasi bisnis dengan hak asasi manusia.

Setiap kegiatan bisnis harus mengakui tanggung jawab sosial dan moral dalam rangka mewujudkan kesejahteraan pihak lain seperti konsumen, karyawan, pemegang saham, dan masyarakat setempat. Konsep CSR dalam Islam mencakup makna yang lebih luas yaitu sebagai manifestasi ketakwaan dan kesadaran akan adanya dimensi ketuhanan dalam kehidupan manusia. Jadi CSR Islami merupakan paradigma yang komprehensif dan holistik karena tertanam beberapa esensi, yaitu: (1) tanggung jawab dalam Islam (daruriyat); (2) keprihatinan sosial terhadap lingkungan; (3) pemenuhan harapan stakeholder serta masyarakat; (4) alat untuk mengurangi ketidakadilan sosial; (4) upaya untuk mendapatkan legitimasi masyarakat terhadap bisnis yang dikelolanya; dan (5) menciptakan lingkungan yang aman dan amanah.

Tujuan syariat Islam dalam mewujudkan kesejahteraan umat juga harus didasarkan pada tujuan untuk menjaga, diri (nafs), akal (aq)), keturunan (nasl), kekayaan (mal), dan yang pokok adalah menjaga iman (din). Islam menetapkan fokus bahwa akuntabilitas perbuatan manusia yang utama akan dipertanggungjawabkan kepada Allah. Dengan demikian maka syariat Islam

12 M. Abdul Mannan, 1997, Teori dan Praktek Ekonomi Islam, PT. Dana Bhakti Prima Yasa, Yogyakarta, Hlm. 358 
Prinsip Keadilan Sosial dan Altruisme dalam Penerapan Sistem

didesain untuk meningkatkan dan memfasilitasi kehidupan manusia dalam mencapai kemaslahatan umat sekaligus pencapaian tujuan akhirat yang kekal.

Perbedaan CSR dalam perspektif barat dan Islam terletak pada konsepsi etika dan moralitas. Barat menetapkan konsepsi etika dan moralitas secara sekuler dimana penerapan CSR berdasarkan pada agenda pemenuhan keinginan stakeholder saja. Sedangkan CSR dalam perspektif Islam berdasarkan pada prinsip-prinsip agama yang harus dihargai dan dipatuhi sebagai wujud ketaqwaan kepada Allah SWT bukan semata-mata untuk mengejar laba secara maksimal atau untuk mendapatkan legitimasi dari stakeholder. Pelaksanaan CSR Islami juga harus dilandaskan pada prinsip-prinsip keadilan dan persaudaraan. Dengan demikian maka CSR dalam Islam bertujuan untuk kesejahteraan dan kebahagiaan (falah) seluruh umat manusia berdasarkan prinsip Islam yaitu kesejahteraan dan kebahagiaan di dunia dan akhirat.

\section{Zakat dan Penerapan Keadilan Sosial}

Instrumen sosial bank syariah dilaksanakan untuk beberapa tujuan yang lebih luas ${ }^{13}$, yaitu: (1) kepatuhan terhadap prinsip Islam yang berkaitan dengan keadilan sosial; (2) untuk menunjukkan pengaruh kegiatan bank syariah terhadap kesejahteraan sosial; dan (3) untuk membantu ummat muslim dalam menjalankan ibadahnya.

Zakat disebut sebagai al ibadah al maly, yaitu pengabdian kepada Allah dalam bentuk pembelanjaan harta benda dan mengandung dimensi sosial serta merupakan manifestasi hubungan antara manusia dengan manusia dengan prinsip mentransfer harta dari yang kaya ke si miskin ${ }^{14}$. Zakat juga merupakan ekspresi rasa syukur kepada Allah dan juga ketentuan agama yang diperintahkan untuk dibayarkan dan diditribusikan.

Prinsip zakat meliputi15: (1) prinsip keyakinan agama yang memerintahkan umatnya untuk membayar zakat sebagai salah satu manifestasi

\footnotetext{
${ }^{13}$ Bassam Maali, Peter Casson, \& Christopher Napier, 2006, Social Reporting by islamic Banks, ABACUS, Vol. 42, No. 2, hlm. 274 201

${ }^{14}$ Muhammad, 2004, Dasar-Dasar Kenangan Islami, Penerbit Ekonosia, Yogyakarta, Hlm.

${ }^{15}$ M. Abdul Mannan, op cit, hlm. 257
} 
agama; (2) prinsip pemerataan dan keadilan yang mendistribusikan kekayaan yang diberikan Allah lebih merata kepada sesama manusia; (3) prinsip produktifitas yang menekankan bahwa pembayaran zakat dilakukan karena hak milik telah menghasilkan produk tertentu; (4) prinsip nalar yang mewajibkan pembayaran zakat oleh orang yang berakal dan bertanggungjawab; (5) pinsip bebas yang menyatakan bahwa zakat dibayarkan oleh orang yang bebas; dan (6) prinsip etika dan kewajaran bahwa zakat tidak dipungut secara semenamena. Secara ekonomik, pelaksanaan pemungutan zakat idealnya dapat menciptakan redistribusi yang merata serta menghapus jurang perbedaan kekayaan si kaya dan si miskin. Zakat juga mampu membantu keseimbangan perekonomian karena mampu menekan laju inflasi.

Zakat juga berperan dalam mencegah kecenderungan menimbun uang dan memberikan dorongan untuk berinvestasi atau menanamkan uang dalam usaha-usaha produktif. Pengelolaan zakat dalam sistem pemerintahan dapat memberikan jaminan sosial bagi seluruh warga negara untuk mendapatkan kesejahteraan dalam bidang ekonomi, pendidikan, kesehatan, dan kebutuhan mendasar lainnya. Keuntungan zakat secara sosial dapat: (1) mengurangi perbedaan dalam pendapatan sehingga masyarakat menjadi lebih beradab; (2) mengurangi tingkat pengangguran dalam masyarakat dan faktor-faktor lain yang menjadi penyebab eksploitasi sumber daya alam.

Zakat merupakan instrumen ekonomi beretika yang penting dalam berkehidupan Islam karena zakat menyediakan mekanisme untuk pembagian sumber daya secara sosial dalam masyarakat muslim ${ }^{16}$. Distribusi pendapatan dan kekayaan dalam zakat tersebut memiliki peran dalam mengurangi kemiskinan sehingga dapat berkontribusi pada pengembangan masyarakat kelas bawah. Zakat membangun rasa persaudaraan dalam Islam (ukhuwah islamiyab) antara kelompok kaya dengan kelompok miskin dan orang-orang yang berkekurangan.

Zakat diambil dari sebagian harta yang wajib dikeluarkan oleh wajib zakat (murakeki) untuk diserahkan kepada penerima zakat (mustabiq) dan dilakukan apabila nisab dan haulnya telah terpenuhi dari harta yang memenuhi

16 AbulHasan M. Sadeq, 1997, Poverty Alleviation: An Islamic Perspective, Humanomics, Vol. 13, No. 3, hlm. 113 


\section{Prinsip Keadilan Sosial dan Altruisme dalam Penerapan Sistem}

kriteria wajib zakat. Implementasi zakat dalam sistem perbankan syariah di Indonesia dirumuskan dalam Pernyataan Standar Akuntansi Keuangan (PSAK) yang menekankan kewajiban bagi bank syariah untuk melaporkan sumber dan penggunaan dana zakat dalam laporan keuangan tersendiri. Sumber dana zakat pada bank syariah dapat berasal dari internal bank maupun pihak lain. Penggunaan dana zakat melalui lembaga amil zakat untuk beberapa pihak yang berhak menerimanya sesuai yang termaktub dalam QS. At Taubah 9:60, yaitu (1) fakir; (2) miskin; (3) pengurus zakat (amil); (4) muallaf; (5) memerdekakan budak (riqab); (6) orang yang terlilit hutang (gharim); (7) orang yang berperang di jalan Allah (fisabilillab); (8) orang-orang yang dalam perjalanan (ibnu sabi); dan (8). Tetapi dana zakat dalam bank syariah tidak diperkenankan untuk menutup penyisihan kerugian aktiva produktif.

Sedangkan implementasi penyaluran zakat oleh bank syariah dalam berbagai bentuk misalnya penyaluran pada program inovatif pada Komunitas Mikro Mustahik Muamalat (KUM3) dalam bentuk pengembangan usaha mikro ${ }^{17}$. Selain itu juga zakat diditribusikan dalam bentuk dana kemanusiaan pada beberapa wilayah yang terkena bencana alam, pengeloaan sekolah anakanak korban bencana alam, dan dalam bentuk beasiswa pendidikan anak-anak yatim korban bencana alam.

\section{Altruisme dan Qardhul Hasan}

Altruisme merupakan perhatian terhadap kesejahteraan orang lain tanpa memperhatikan diri sendiri. Nilai-nilai altruistik dapat berupa loyalitas, kepercayaan, kejujuran, kerjasama, dan kepedulian untuk berbagai tanpa mengharapkan imbalan. Tujuan altruisme yang utama aalah untuk mencapai sebuah harmoni. Al-Qur'an sebagai pondasi tatanan Islam menggambarkan nilai-nilai altruistik yang ditekankan pada distribusi pendapatan bagi kebutuhan individu dan juga dalam bentuk amal kebajikan yang diditribusikan bagi pihak lain (filantropi) ${ }^{18}$. Berdasarkan nilai-nilai altruistik tersebut maka pembangunan

\footnotetext{
${ }^{17}$ Laporan Tahunan Bank Muamalat Indonesia, 2006, Annual Report: Improve Quality, Go Retail

18 Ataul Hug Pramanik, 1998, The Role of Institutions for Promoting Social Economic, Moral and Spiritual Development Based on Altruism rather than Egosim, Humanomics, Vol. 4, No. 2, $25,24-48$
} 
ekonomi adalah pembangunan yang meletakkan dasar-dasar yang kuat bagi pengembangan dan kesejahteraan seluruh anggota masyarakat.

Keseimbangan sosial tercapai bilamana kebutuhan akan hak diimbangi dengan pelaksanaan kewajiban dalam masyarakat. Sedangkan ketidakseimbangan sosial dapat terjadi jika sistem nilai dan norma yang mengatur interaksi dalam masyarakat atau negara tidak ditegakkan. Kewajiban untuk menginternalisasi dan mematuhi nilai-nilai yang telah ditentukan dalam masyarakat merupakan wujud komitmen dalam menciptakan harmoni dan keseimbangan sosial tersebut.

Tujuan pembangunan yang komprehensif adalah pembangunan yang melibatkan seluruh aspek tidak hanya aspek ekonomi tetapi juga sosial, moral, dan spiritual manusia. Pembangunan memperluas peluang individu untuk berpartisipasi pada seluruh aspek kehidupan. Berdasarkan nilai-nilai altrusitik maka pembangunan merupakan pengembangan untuk seluruh individu yang menghilangkan unsur egoisme dalam diri masing-masing individu. Nilai altruistik ini merupakan salah satu syarat terciptanya lingkungan yang berkeadilan sosial, humanis, dinamis, stabil, dan penuh harmoni.

Salah satu bentuk penerapan nilai-nilai altruistik dalam penerapan sistem perbankan syariah ditunjukkan oleh keberadaan dana qardul hasan. Qardul hasan merupakan sebuah pinjaman kebajikan yang ditetapkan tanpa dikenakan tarif eksplisit bunga implisit atau tambahan biaya tertentu. Niat pinjaman ini hanya untuk mencari pahala dari Allah SWT. Penyaluran dana ini merupakan salah satu kontribusi bank syariah kepada umat agar lebih produktif dan berdaya sehingga dapat berperan dalam masyarakat.

Dana kebajikan atau qardhul hasan ini pada bank syariah dapat berasal dari sumber-sumber sebagai berikut: (1) infaq; (2) shodaqah; (3) hasil pengelolaan wakaf yang sesuai dengan peraturan perundang-undangan yang berlaku; (4) pengembalian dana kebajikan produktif; (5) denda; dan (6) pendapatan non halal. Sedangkan penggunaannya dalam beberapa bentuk, yaitu: (1) dana kebajikan produktif; (2) sumbangan; dan (3) penggunaan lainnya untuk kepentingan umum. 
Prinsip Keadilan Sosial dan Altruisme dalam Penerapan Sistem

\section{Pelaporan Sosial dalam Perspektif Islam}

Setiap organisasi bertanggungjawab dalam menjaga nilai-nilai etika dan moralitas yang berlaku dalam masyarakat. Islam mengatur mengatur hak dan kewajiban individu maupun organisasi dalam penerapan nilai-nilai etika dan tanggung jawab sosial. Pelaporan sosial dan lingkungan organisasi dapat bersifat normatif, utilitas, maupun untuk mendapatkan legitimasi. Namun demikian dalam Islam, pengungkapan sosial dilakukan untuk memenuhi tujuan-tujuan syariat dan penerapan nilai-nilai Islami. Tujuan utama dari sebuah bisnis Islam adalah untuk memenuhi kehendak Allah, melalui tindakan yang sesuai dengan Alquran dan Sunnah. Islam menganggap bekerja merupakan bagian dari ibadah. Tujuan pencapaian keuntungan diabsahkan dalam Islam tetapi tujuan ini tidak diperbolehkan bertentangan dengan ketentuan syariat Islam.

Pelaporan sosial bank syariah terjadi dalam kerangka hubungan sosial dalam persepektif Islam serta menggambarkan pemahaman tentang makna akuntabilitas, keadilan sosial, dan ukhuwah Islamiyah. Penyampaian informasi dalam pelaporan sosial merupakan bentuk tanggung jawab kepada pihak-pihak yang memiliki keterkaitan dengan bank (stakeholder) baik langsung maupun tidak langsung. Hak stakeholder terhadap informasi untuk menilai seberapa besar tujuan-tujuan sosial telah dilakukan oleh bank.

Islam menekankan konsep tanggung jawab dan keadilan sosial dalam bentuk persaudaraan (ukbuwah). Larangan riba, kewajiban membayar zakat, dan penyediaan dana qardul basan adalah contoh riil dari penekanan Islam terhadap keadilan sosial. Islam menghormati kepemilikan individu tetapi tidak mutlak. Pemilik bertanggung jawab untuk menggunakan sumber daya yang tersedia sesuai dengan kehendak Allah dan kepentingan masyarakat.

Implikasi pelaporan sosial bank syariah harus mengungkapkan semua informasi yang diperlukan umat tentang operasional bank. Dalam konteks Islam, umat memiliki hak untuk mengetahui bagaimana organisasi yang merupakan bagian dari umat memiliki pengaruh terhadap kesejahteraannya. Kewajiban untuk mengungkapkan kebenaran adalah masalah yang sangat penting dalam konteks Islam, dan kewajiban ini berlaku pula untuk kegiatan bisnis. Bisnis syariah dituntut, seperti halnya bagi individu, untuk melakukan 
kegiatan amal dan membantu orang miskin dan orang yang membutuhkan. Hal ini ditekankan dalam banyak ayat-ayat Alquran dan Sunah. Informasi yang diberikan oleh bank syariah, di samping untuk menunjukkan kepatuhan dengan Syariah, juga harus membantu umat Islam dalam melakukan tugas keagamaan mereka, terutama pembayaran zakat.

Menurut Pernyataan Standar Akuntansi Keuangan (PSAK), bank syariah harus mengungkapkan catatan atas laporan sumber dan penggunaan dana zakat tetapi tidak terbatas pada:

- Sumber dana zakat yang zakat berasal dari internal bank syariah

- Sumber dana yang zakat yang berasal dari eksternal bank syariah

- Kebijakan penyaluran zakat terhadap masing-masing asnaf

- Proporsi dana yang disalurkan untuk masing-masing penerima zakat diklasifikasikan atas pihak terkait baik itu pihak-pihak yang mempunyai hubungan istimewa dan pihak ketiga

Sedangkan pengungkapan dalam catatan atas laporan sumber dan penggunaan dana kebajikan juga tidak terbatas pada:

- Sumber dana kebajikan

- Kebijakan penyaluran dana kebajikan kepada masing-masing penerima

- Proporsi dana yang disalurkan untuk masing-masing penerima dana kebajikan diklasifikasikan atas pihak terkait baik pihak yang mempunyai hubungan istimewa dengan bank dan pihak ketiga

\section{Implementasi Zakat dalam Pengentasan Kemiskinan}

Tanggung jawab sosial semestinya tidak hanya terbatas pada distribusi kekayaan atau pendapatan tetapi juga harus sebagai bentuk kepedulian sosial yang terbebas dari unsur-unsur eksploitatif. Islam memiliki upaya yang sungguh-sungguh dalam mengurangi kemiskinan dalam masyarakat. Pengentasan kemiskinan yang ideal selain meningkatkan pendapatan masyarakat juga harus memberikan kesempatan yang sama bagi setiap individu untuk memperbaiki status sosialnya dalam masyarakat. 
Prinsip Keadilan Sosial dan Altruisme dalam Penerapan Sistem

Implementasi program pengentasan kemiskinan dalam perspektif Islam harus mencakup beberapa dimensi yaitu positif, preventif, dan korektif ${ }^{19}$. Ukuran keberhasilan dimensi positif dalam pengentasan kemiskinan dapat diidentifikasi melalui meningkatkan pertumbuhan, distribusi pendapatan fungsional pendapatan yang adil, dan memberikan kesempatan yang sama terhadap seluruh masyarakat dalam meningkatkan standar hidupnya. Kondisi ekonomi seseorang tergantung antara lain pada kategori pendapatan negara dan usahanya. Jika ukuran pendapatan nasional kecil maka pendapatan yang terdistribusi juga semakin sedikit. Islam telah memberikan sistem panduan dalam menjalankan etika kerja yang positif, penghematan konsumsi, dan mendorong perilaku produktif. Dalam sistem ekonomi Islam yang efektif dan efisien maka setiap individu: (1) akan mendapatkan segala sesuatu berdasarkan apa yang diupayakan; (2) menjalankan hidup berdasarkan aturan-aturan yang ditentukan; (3) setiap individu dalam masyarakat lebih produktif; dan (4) tidak adanya pemborosan. Allah SWT memerintahkan keadilan dan kebajikan dengan pembangunan yang merata dan memberikan kesempatan yang sama bagi setiap masyarakat sehingga kemiskinan dan dikurangi.

Dimensi preventif dalam pengentasan kemiskinan meliputi pelarangan terhadap praktik-praktik yang menyebabkan terkonsentrasinya pendapatan dan kekayaan hanya pada kelompok-kelompok tertentu. Ketimpangan pendapatan dan kekayaan dapat dicegah melalui peran pemerintah dalam pengaturan fasilitas publik yang berkaitan dengan kepentingan umum. Cara lain dapat dilakukan melalui pencegahan terhadap praktik-praktik yang merugikan seperti perjudian, penyuapan, aktifitas yang berhubungan dengan riba, dan bentukbentuk penipuan lainnya.

Sedangkan dimensi korektif dalam pengentasan kemiskinan dapat dilakukan melalui zakat dan transfer kekayaan dalam bentuk kegiatan-kegiatan amal dan tanggung jawab sosial lainnya. Tujuan utamanya adalah untuk mengentaskan kemiskinan yang didistribusikan pada pihak-pihak yang berhak menerima. Jika zakat dilembagakan secara efektif maka diharapkan dapat

${ }^{19}$ Sadeq2, 1997, op cit, hlm. 116 
memobilisasi dana yang besar yang dapat dimanfaatkan dalam pengentasan kemiskinan, mencerdaskan kehidupan bangsa, dan membangun kesehatan masyarakat secara fundamental. Dengan demikian maka zakat memiliki peran penting dalam upaya pengurangan kemiskinan serta pemberdayaan masyarakat.

\section{Kesimpulan}

Tujuan pembangunan dalam perspektif Islam adalah tercapainya kesejahteraan secara material dan spiritual. Bank syariah sebagai lembaga keuangan yang menjalankan fungsinya sebagai lembaga penghimpun dan penyalur dana kepada masyarakat memiliki peran penting dalam membantu keberhasilan pembangunan. Peran bank syariah dapat diwujudkan melalui implementasi tanggung jawab sosial dan nilai-nilai altruistik. Keadilan sosial dalam bank syariah dilaksanakan melalui distribusi zakat kepada pihak-pihak yang berhak menerimanya. Sedangkan nilai-nilai altruistik diimplementasikan melalui penyaluran dana kebajikan (qardhul hasan) dalam bentuk pinjaman tanpa biaya implisit maupun eksplisit.

Zakat dan qardul hasan disalurkan bank syariah tidak terbatas pada tujuan pengentasan kemiskinan tetapi juga kepedulian sosial yang lebih luas serta mendorong perilaku produktif umat. Dengan demikian maka dimensi positif, preventif, dan korektif dalam pengentasan kemiskinan dapat dicapai oleh bank syariah melalui sistematisasi zakat dan qardhul hasan dalam sistem operasional bank syariah yang dapat dipertanggungjawabkan secara formal dan sosial. 
Prinsip Keadilan Sosial dan Altruisme dalam Penerapan Sistem

\section{DAFTAR PUSTAKA}

Al Qur'an dan Terjemahnya, 1971, Yayasan Penyelenggara Penterjemah/ Penafsir

Abdel Karim, R. A., International Accounting Harmonization, 2001, Banking Regulation, and Islamic Banks, The International Journal of Accounting, 36, 169-193

Antonio, M. S., 2001, Bank Syariah dari Teori ke Praktik, Gema Insani, Jakarta

Chapra, M.U, dan Ahmed, H., 2002, Corporate Governance in Islamic Financial Institution, Jedah: IRTI-IDB

Chapra, M. U., 2009, The Global Financial Crisis: Can Islamic Finance Help?, Insights, Vol. 1, No. 4, 27-38

Cihak, M. dan Hesse, H., 2010, Islamic Bank and Financial Stability, Journal of Financial Services Research, 38, 95-113

Dusuki, A. W., 2008, Understanding the Objectives of Islamic Banking: a Survey of Stakeholders' Perspectives, International Journal of Islamic and Middle Eastren Finance and Management, Vol. 1, No 2, 132-148

Hearn, B., Piesse, J., dan Strange. R., 2012, Islamic Finance and Market Segmentation: Implications of the Cost of Capital, International Business Review, 21, 102-113

Laporan Tahunan Bank Muamalat Indonesia, 2006, Annual Report: Improve Quality, Go Retail

Maali, B., Casson, P., dan Napier, C., 2006, Social Reporting by Islamic Banks, ABACUS, Vol. 42, No. 2, 266-289

Mannan, M. A., 1997, Teori dan Praktek Ekonomi Islam, PT. Dana Bhakti Prima Yasa, Yogyakarta

Mehmet, O., 1997, Al-Ghazzali on Social Justice: Guidelines for a New World Order from an Early Medieval Scholar, International Journal of Social Economics, 1203-1218 
Muhammad, 2004, Dasar-Dasar Keuangan Islami, Penerbit Ekonosia, Yogyakarta Pramanik, A. H., 1998, The Role of Institutions for Promoting Social Economic, Moral and Spiritual Development Based on Altruism rather than Egoism, Humanomics, Vol. 4, No. 2, hal. 24-48

PSAK, 2006, Penyajian Laporan Keuangan Syariah, Ikatan Akuntan Indonesia

Sadeq, A. M., 1996, ethico-economic Institution of Zakah: An Instrument of Self-Reliance and Sustainable Grassroot Developmnet, Humanomics, Vol. 12, No. 2, 47-69

Sadeq, A. M., 1997, Poverty Alleviation: An Islamic Perspective, Humanomics, Vol. 13, No. 3, 110-134

Siddiqui, A., 2008, Financial Contracts, Risk and Performance of Islamic Banking, Managerial Finance, Vol. 34, No. 10, 680-694 
Prinsip Keadilan Sosial dan Altruisme dalam Penerapan Sistem 